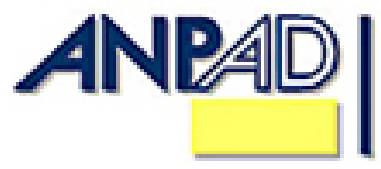

Available online at http://www.anpad.org.br/bar

\title{
Rural Heritage of early Brazilian Industrialists: its Impact on Managerial Orientation
}

Copyright (C 2011 Brazilian Administration Review. All rights reserved, including rights for translation. Parts of this work may be quoted without prior knowledge on the condition that the source is identified. 


\begin{abstract}
The understanding of modern management in peripheral countries does not take into account research into their historical background that has come a different route from the Anglo-Saxons. In this study we shall be analyzing the case of Brazil, where the modernization process has been marked by a unique colonial heritage. The central hypothesis is that strengthening of the farming system that was inherited from the colonial period was a decisive factor when the country fell behind the social, political and economic modernization processes that were taking place at that time in other parts of the world. We set out with the premise that the persistence of rural logic in social and political spheres in republican Brazil was a determining factor for the configuration of industrial management with traits that were characteristic of patrimonialist societies. These are: (a) opting for protectionism based on political influence and privileges extended to the businessman, which characterizes relationships among the economic elite in Brazil; and (b) the subordination of formal authority and the technical competence of the professional manager to patriarchal personalist logic, which favors family ties and personal loyalty.
\end{abstract}

Key words: Brazilian management; Brazilian social historiography; industrialization in peripheral countries; rural values. 


\section{Introduction}

Modern management has been seen as an institution that is the fruit of the process of modernization in the world, where capitalism, industrialization and rationalization are the fundamental pillars (Bendix, 1974; Braverman, 1998; Pollard, 1965). Thus, the modern idea of management is consolidated as one of the institutions that are most representative of this period of history, centered on the instrumental rationality that emerged particularly with the development of industrial capitalism.

In this sense, England, since the eighteenth century, and the United States, since the nineteenth, have been the central world leaders in this process (Hobsbawm, 1988, 1999). For this reason, they should be considered as the main arena of management gestation (Bendix, 1974; Jacques, 1996; Pollard, 1965). On the other hand, there are countries that took on a marginal role during the spread of industrial capitalism. These were more dedicated to the production of primary goods and were unable to keep up with the industrial powers (Hobsbawm, 1999). Consequently, they were forced to become dependent on an industrial path paved by foreign countries. Certainly, one way to express this dependence is that of the management maxims of the English-speaking countries, especially those built in the United States, where management has been seen as one of the most important cultural exports (Jacques, 1996). Although this importing of managerial techniques is recognized as a positive process for improving management in undeveloped countries, we point out its ideological sense by appealing to a historical dependence view. For example, despite its already significant industrial and technological development, Brazil is still conditioned to importing management models and theories that originated in the North Atlantic and which are not always suitable for the Brazilian business reality (Caldas \& Wood, 1997).

For this reason, the understanding of modern management in historically dependent countries must take into account the literature concerning their historical background which, based on different factors from those that sustain modern institutions, has come a different route from the Anglo-Saxons. Therefore, in this study we shall be analyzing the case of Brazil, where the modernization process has been marked by a unique colonial heritage. The aim of this analysis is to point out that the roots of certain specifics of Brazilian management lie in the socio-political background of the country.

The main contribution we have sought in this study is to reveal the decisive role of Brazilian agricultural institutions in the shaping of management in Brazil, considering their influence on the establishment of Brazilian industrial society. During the nineteenth century when Brazil constituted its national identity, the strengthening of the farming system was a decisive for the country to fall behind the social, political and economic modernization processes. On the other hand, in comparison with other countries involved in modernization processes, Brazil's path seems to be anachronistic. While the United States was undergoing the second industrial revolution in the second half of the nineteenth century as the result of the consolidation of republican federalism (Jacques, 1996), Brazil was having difficulties in abandoning the slave economy; furthermore, a hundred years after the French revolution, Brazil was taking the first tentative steps in the republican regime, but still holding on to patrimonialist relations (Faoro, 2001).

We believe that Brazil's institutional anachronism is the basis of its managerial pattern. In fact, one of the main consequences of the introduction of modern management in Brazil was its hybridization with traditional mentality. The persistence of rural logic in social and political spheres in republican Brazil was a determining factor for the configuration of industrial management with traits that were characteristic of patrimonialist societies, bearing in mind that such cultural conditions were relevant in the unfolding of the industrialization process (Leff, 1972, 1982; Prado, 1971; Stein, 1957). This assimilation is most evident in the patriarchal configuration of the management model adopted by the first big Brazilian industrial groups a pattern that continues until the present day. Furthermore, we see a hangover from colonial rural society in the protectionist relationship between the first industrialists and the State, characterized by clientelism (Castor, 2002). 
In order to understand the formation of Brazilian industrial management, it is not enough to look up the birth of the first factories in the country and see this as the event that supposedly led to industry in Brazil. It is necessary to observe certain nuances of the general elements that shaped the identity and imaginary of Brazilian society.

Considering that of the five centuries since the discovery of Brazil, three were a colonial period, this surely must have been an important historical time in the shaping of the institutions that founded Brazilian society (Holanda, 1995; Prado, 1971). From an institutional viewpoint, the main inheritance from the long colonial period may be referred to as a rural model, a socio-economic system for organizing Brazilian colonial life.

There now follows a brief reflection on the Brazilian colonial institutional model. Following that, we will deal with the implications of this model in the historical trajectory of Brazil in the nineteenth century. We will then discuss how this rural institutional pattern conditioned the pace of Brazilian modernization, as well as how it determined the Brazilian managerial path. Finally, we discuss some implications for Brazilian management research and further studies.

\section{The Rural Model of Colonial Brazil}

The imaginary of nineteenth-century Brazilian society is mostly based on the cultural traits that were consolidated during the three centuries of colonization. During this time, the ethnic mixture of the three races that made up Brazil was remarkable: These races were the Portuguese, the Blacks and the native Indians. Holanda (1995) points out that the Portuguese model determined the mind-set of the elite and, therefore, the political and economic configuration of Brazil. The author emphasizes that the Portuguese had no racial pride and this led them to accept partially Indian and Black culture. As a result, the elite adopted habits, techniques and behavior patterns that were characteristic of the dominated races.

Even so, the plasticity of the Portuguese and their descendants was conditioned to the distancing of the elite from the inferior castes of society, which had begun with the formation of their patrimonialist society. In this sense, patrimonialism is the dominant group's ability to impose their will and whims on the rest of the population, a situation which was made possible by the relative docility of the lower-ranking social groups (Holanda, 1995).

This trait is linked to mandonismo ${ }^{(1)}$ or 'commandism', an important element for ordering social relations in Brazil and seen throughout the country's history and in the simplest aspects of the daily lives of ordinary people even today (DaMatta, 1992). It derives from the personal power of a local leader, based on well defined oligarchic structures. According to Carvalho (1998, p. 133), those who have power in this system are

those who are in control of some strategic resource, generally land ownership, and who use this power over the rest of the population, a personalistic and arbitrary form of domination that blocks free access to the market and political society.

In this sense, Brazilian commandism stems from the patriarchal logic of the main socioeconomic organization of the colonial period: the big agricultural enterprise.

The fact that the economy of the colonial period was centered on the model of big agricultural enterprise was a decisive factor in the formation of the Brazilian elite. Owing to the need to guarantee the settlements, the Portuguese government opted for an agriculture-based colonization model, centered on the large scale production of articles with a high commercial value on the European market. In this context, this monoculture economy for exports was broadened significantly, starting with sugar cane in the Brazilian north-eastern region (Baer, 2007; Canabrava, 1985; Furtado, 1999). 
This is why the sugar mill was the most representative economic model of that period, due to its huge impact on the economic, social and political structure of Brazilian colonial life (Canabrava, 1985).

One of the factors that led to sugar production becoming the most significant economic model was the fact that the operationalization of the mill required simple technology, with the only really necessary resources being land and labor (Canabrava, 1985). Considering that Portuguese settlement policy made land a resource of easy access, the only factor of production that really mattered was labor (Canabrava, 1985). The problem was that it was difficult for the indigenous people to acquire the minimum conditions of discipline required in the systematic and methodical work that farming involved on a large scale. Thus, the option that remained was to resort to black labor, captured from the Portuguese colonies in Africa and enslaved (Holanda, 1995). As a consequence, mercantilism was intensified through the slave traffic, stimulating the domestic economy (Baer, 2007; Skidmore, 1999) and emphasizing slave ownership as a foundation of the nineteenth-century economic system (Graham, 1981; Holanda, 1995).

According to Freyre (2003), the social and political dimension of a semi-feudal nature for farming was personified in the personalistic relations within the community that sprang up around the company. In this sense, the author refers to the sugar mill as a patriarchal economy, i.e., a productive model with traits of strong family ties and affection that are part of the concept of the extended family. By extended family, we mean a parental structure made up of numerous members of the official family (official being through religious marriage), but also the aggregated, the members of the community surrounding the land who, through compadrismo ${ }^{(2)}$, became part of the inner circle of the landlord. The practice of arranged marriages and baptisms reflected the importance given to family ties and affection in social relationships on colonial rural property. As Freyre (2003, p. 81) puts it:

The family, rather than the individual or the State or any business venture, was the biggest factor in Brazilian colonization from the sixteenth century onwards, the productive unit, the capital that worked the land, set up farms, bought slaves, cattle, tools, the social force that became political and became the most powerful colonial aristocracy in America. Over them, the king of Portugal almost reigned without governing.

Symbolically, the big house, the building that was the headquarters of the rural property in which the official family of the landlord lived, illustrated the preponderance of patriarchal power in Brazilian colonial society. Located on high ground on the land, this house was the political center of the community, to which all were summoned or to which all retired of their own free will to do the bidding of the landlord. The big house was a kind of Brazilian fortress, where all the economic, political and even religious decisions were made and sent out to be obeyed. The big house is an example of the sovereignty of the landlord in colonial Brazil, a power that was wielded over even the most powerful political institution of the time. As can be seen in this comment by Freyre (2003, p. 271):

In Brazil, the cathedral or church, which was more powerful than the king himself, would be replaced by the big house and the mill. Our social background, like that of Portugal, was built by solidarity of ideals or religious faith, which helped us overcome political fatigue or the mysticism or awareness of race. But the church that helped form the Brazilian background was not the cathedral with its bishop, where people went to complain about miscarriages of secular justice; neither was it an isolated church or monastery or abbey, where people go to see criminals being flogged and beggars and the needy go for bread and leftovers. It was the chapel of the mill. There was no clericalism in Brazil. The priests of the Company of Jesus vanished, overcome by oligarchy and the nepotism of the landlords and slave owners.

Another important conception that revealed the mentality of the Portuguese colonist eradicated in Brazil was the tag of adventurous spirit. According to Holanda (1995), the adventurous spirit was a trait of Portuguese ethnicity that represented the drive of the colonist for easy and quick profit, almost always the result of a daring venture and marked by prodigality and imprudence. It showed a person interested in immediate and extremely profitable success, someone willing to take great risks to 
make enormous gains with little effort. For the adventurer, work is considered below his dignity. Canabrava (1985, p. 201) states that "the Portuguese emigrant did not move to the colonies merely to become a wage earner; he aspired to wealth and importance that stemmed from his becoming the owner and exploiter of large tracts of land".

In part, this temperament accounts for the option to resort to slave labor. It also explains why it was so difficult to abolish slavery. Furthermore, the relationship with property, which, in Brazil tended to be wasteful, is another example of this adventurous spirit. Land was easy to come by, either because there were no strict laws concerning the concession of allotments (Canabrava, 1985; Freyre, 2003), or because when it became necessary to expand, many simply occupied the land illegally. For this reason, there was no need to care for the land and it was easy to work the soil constantly until it was spent and then move elsewhere. This is why Holanda (1995) believes that large farms in colonial Brazil were closer to extractivism than to the farming spirit itself, where the farmer is emotionally tied to the land and his profession.

Lack of care was also shown when it came to the other essential item in colonial Brazilian farming: the slave. Blacks were an interesting option for slavery because they were easily acquired through traffic, which was easier than worrying about living conditions in slave quarters, which were important for the survival, and the breeding and health of the people who provided this labor. In other words, it was better to enfranchise the slave who was tired from overwork or sick than to look after him since others could easily be obtained through trafficking (Skidmore, 1999). This attitude accounts for the difficulty the Brazilian government faced when it came to putting an end to slave trafficking as requested by the British (Graham, 1966, 1968, 1981).

Still on the subject of the wasteful attitude of the adventurous colonists, concern over improving farming practices tended towards technological precariousness, which lasted into the republican days (Ridings, 1977). Thus, the monoculture of exporting was like plundering and, for this reason, required ownership of large tracts of land (Holanda, 1995). Along with the aforementioned colonizing policy of land leases, this factor encouraged landed estates, resulting in huge concentration of wealth in the hands of a few owners, which further increased the power of the rural oligarchy (Canabrava, 1985; Faoro, 2001; Holanda, 1995; Skidmore, 1999). In comparison with other plantation economies, especially the southern states of the U.S.A., this predominance for landed estates was a crucial factor. For example, it can account for the marked differences in political and institutional conditions that characterized nineteenth-century Brazil's falling behind countries whose history and geographic conditions were similar to our own (Furtado, 1999; Leff, 1972, 1982).

In short, the sugar mill was not only the most important venture during the colonial period but also the first manufacturing venture in the country, the first system that led to a form of manufacturing management. Therefore, it is not wrong to consider it as the organization that developed the first model for management to be institutionalized in the country, since this model is an important reference for other ventures after the colonial period, such as the first Brazilian factories, which first appeared during imperial times (Luz, 2004; Stein, 1957). It is also a reference even for the structure of the state, which is formed with political independence, taking into account the narrow relations between the State and the oligarchies and other interest groups connected to these oligarchies with similar aims. It is this influence that we now intend to show in the following analysis of Brazil during the nineteenth century.

\section{Nineteenth-century Brazil}

Nineteenth-century Brazil was marked by the end of the colonial period of the three previous centuries owing to political independence. This independence began with the transfer of the Portuguese royal family court to the Brazilian colony as they escaped the revenge of Napoleon's army in Europe. At this time, the Portuguese government changed its stance on Brazil. It was no longer a 
colony only served the interests of the Crown through taxes and resources, a logic of exploitation and with no concern for the natives and Portuguese expatriates (Fausto, 1999; Skidmore, 1999). With the transfer, the Prince Regent, João VI, intended to make Brazil the center of the kingdom and, to this end, set out to write a set of acts that would consolidate this intention. Of these acts, the first (and one of the most significant) was the opening of Brazilian ports to countries other than Portugal (Fausto, 1999; Luz, 2004; Skidmore, 1999).

On the other hand, Independence in 1822, rather than an armed revolutionary act, was simply the consolidation of a political process that had begun in the late eighteenth century. It was a consequence of internal pressure from the Brazilian upper classes who were dissatisfied with the crippling economic policies of the Portuguese (Fausto, 1999; Skidmore, 1999) and external pressure from the English, as the independence of Brazil would inevitably benefit their imperialist policy (Graham, 1968). Thus, unlike Spanish and English America, the independence of Brazil was a peaceful affair and indeed provided political continuity since it led to no changes in the economic and social structure of the colonial period (Skidmore, 1999). This continuation was due to the rural oligarchies that remained strong and their influence on Brazilian policy.

The Empire had been consolidated by the legitimacy that the politically elite Conservative Party had granted it (Needell, 2001). The political logic of this period was no different from that of the colonial period: the State acted on behalf of special interest groups and individuals in exchange for political legitimacy and other favors. In fact, it was actually clientelism, another important cultural trait of Brazilian politics left over from the colonial period (Carvalho, 1998; Faoro, 2001; Holanda, 1995).

As for the economy, in spite of the great historical importance of sugar cane and tobacco in Brazilian foreign trade policy, in the mid nineteenth century, coffee became the most important export, shifting the center of economic agricultural activity from the north-east to the south-east of the country. Furthermore, it marked a transition to a new social panorama since it was coffee that propelled the country into the modern era because of the growing demand for it, a reflection of European (and later North American) industrialization and urbanization. It was also, it was in the interests of coffee producers that the country managed to put an end to the long and difficult process of the transition from slave labor to paid labor and from a monarchy to a republic.

In addition to being supported by the institutionalization of a rural way of life in Brazilian society, the political ascension of the Coffee Barons during the nineteenth century was directly linked to the interest of the English in the effective participation of Brazil in the world market. Actually, it was ideologically founded by liberalism and the worldwide division of labor. Thus, the pact between the English and the Coffee Barons, in truth, aimed to maintain the economic hegemony of the United Kingdom on the world stage owing to the sale of British industrialized goods to the rest of the world and the easy access of the British to raw materials (Graham, 1968; Prado, 1971; Skidmore, 1999).

Paradoxically, the patriarchal social structure began to fade in the wake of the transformations triggered by the development of the coffee export economy. Becoming increasingly complex, this economic model required a larger number of intermediaries in the state bureaucracy, international trade and the financial system (Graham, 1968; Ridings, 1977; Skidmore, 1999). This led to the development of urban centers, especially in the second half of the century. These new centers, in their turn, were adapted to mirror European cities and gradually incorporated their respective lifestyles. Thus, there arose urban interest groups, which spread European-style ideals such as positivism, abolitionism and republicanism. However, these ideas were incorporated into Brazilian society through copycatting foreign culture (especially European in the nineteenth century) rather than actually dealing legitimately with domestic political and social matters.

Even considering that the new modernization movements of the fledgling urban elite reflected an unusual idealism, they played an important role in the achievement of difficult transformation processes in the Brazilian nineteenth-century social order. A significant fact in this was the simultaneous nature of the political events involving the abolition of slavery and the proclamation of 
the republic in the latter two years of the 1880s. Nevertheless, considering that this political and social modernization process in Brazil was consolidated from a society that was strongly marked by institutions of the Brazilian agricultural model, we begin with the hypothesis that this process was decisively determined by the institutional strength of the farming society.

Firstly, we must consider that the agricultural institutions that were consolidated in Brazil in the nineteenth century played a decisive role in the pace of modernization which, despite interest in political and economic modernization already being present in the early nineteenth century (Skidmore, 1999), only came to fruition in the late nineteenth and early twentieth century. Furthermore, the influence of the agricultural institutions in the modernization of Brazil may be measured by the way in which they pushed some of their more marked traits into modern institutions, many of them especially contrary to some of the premises of this new order. This difficult transition can be assessed by the struggle for industrialization in Brazil, which dragged on for most of the nineteenth century, becoming viable only in the early twentieth.

\section{The first (frustrated) efforts at industrialization in Brazil}

Industrialization in Brazil arose at different critical moments, most of them being in more recent times, i.e., the critical economic and political events and world wars of the early twentieth century (Baer, 2007). However, the efforts of the government to bring about industrialization may be said to have begun objectively during the time that the Portuguese royal court was established in Rio de Janeiro in the early nineteenth century (Luz, 2004). These efforts, despite sharply reflecting illuminist thinking that industrialization was beneficial to the economic and social development of a country, were not in the interest of the upper classes with their landed estates, especially in the peak days of coffee production in the second half of the nineteenth century.

The direct efforts of the recently established Portuguese government in the country to implement industrial activity in Brazil began in the very early nineteenth century. They reflected the interest of certain counselors of the monarch at the time in European progressist ideas. They viewed the development of the industrial economy as a broad question with direct implications for the sociodemographic status of nations. Following the first decree in favor of industry in Brazil, came a number of other acts that were meant to encourage the interest of investors in this specific economic sector. However, the nature of these incentives was not in line with the ideas of liberal philosophy as they were too protectionist and benefited specific sectors, those whose development was directly linked to the interest of influential people in the government.

The frustration of the efforts in favor of industrialization was due to the fact that the government itself had contradictory attitudes to the subject. This was because, despite being extremely interested in implementing and intensifying industrial activity in the country, the imperial government depended on customs tariffs on imported industrialized products which, for most of the nineteenth century, was the government's main source of taxation (Luz, 2004). This paradox is accounted for mainly by the tendency toward clientelism in determining public policies (Faoro, 2001), a hangover from the colonial period that continued up to the days of the republican regime. It also conditioned the country to live in a system of pseudo-capitalism, i.e., a regime of imports/exports in a world that had already established industrial capitalism with a rational social division of capitalist production, but which internally lived under a patrimonialist regime, ruled by traditional values and pseudo-feudal mechanisms (Faoro, 2001; Prado, 1971).

Besides the customs tariffs, the attitude of the government concerning domestic industry was determined by pressures from a number of interest groups that joined together in the nineteenth century, the rural oligarchies, merchants and English industrialists (Ridings, 1977). In fact, defense of industrialization in the early nineteenth century had been established without compromising the interests of the agricultural export economy. It was only in the second half of the century that the landed elite became totally opposed to industrialization, especially the Coffee Barons. Thus, in the early nineteenth century, industrialization was seen by some members of the government as an 
alternative to a serious social problem, the comfort of an 'idle' class, i.e., free individuals who were not landowners and were out of place in the agricultural-slavery economy (Luz, 2004; Skidmore, 1999; Stein, 1957).

Joined to these interests of the agricultural economy was the growing need to generate dividends for the national treasury, which was increasingly compromised by the massive spending of the State, a typical characteristic of Brazil since the colonial period (Skidmore, 1999). New military expenditure following independence and the ongoing investment in public works (especially for the urbanization of Rio de Janeiro and the development of transport and communications in the vast expanses of Brazilian territory) made the public coffers increasingly dependent on customs tariffs (Baer, 2007; Luz, 2004; Skidmore, 1999; Stein, 1957).

Finally, along with these political conditions of the mid nineteenth century there were other decisive factors that frustrated the initial enthusiasm for industry in Brazil, two of which deserve to be mentioned: the lack of credit for industry, due to the mistrust and uncertainty of investors and banking institutions concerning the chances of success for these new ventures, plus the fact that there were more profitable economic activities to become involved in (Luz, 2004; Stein, 1957); the lack of skilled labor to work in industry, either due to lack of qualifications or because the work force at the time was mainly slave labor used for farming (Stein, 1957).

After this first frustrated effort to begin industrialization, it would only be in the late nineteenth century that two important events would determine a new direction for domestic industry. With the abolition of slavery and the new republican regime in the late 1880s, the industrial economy had a new chance for growth, aided especially by excess capital on the financial market (which was up to that time dedicated to the acquisition of slaves). In addition, the growth of the industrial economy was supported by the rise in immigration from Europe, with people who were more familiar with the factory system and who initially came to provide labor for the farm lands (Luz, 2004; Skidmore, 1999; Stein, 1957). For this reason there was a great improvement in factories with the end of slave labor, since abolition led to a renewed work force due to the political incentives for European immigrants or the exodus of former slaves from the countryside to the towns (Skidmore, 1999; Stein, 1957). Furthermore, with the abolition of slavery in 1888, some of the financial capital invested in the country was no longer invested in slavery and was relocated to industrial ventures (Luz, 2004).

Therefore, the first significant period of growth in Brazilian industry was the early twentieth century, especially because of the development of the internal market, spurred on by the excellent economic results of coffee sales at the turn of the century (Dean, 1969). Moreover, the aforementioned social and political conditions of the late nineteenth century were also decisive to industrialization, considering that these conditions provided a structure for greater industrial growth (Baer, 2007; Dean, 1969; Skidmore, 1999). Finally, it has been noted that the consolidation of industry was due to a direct incentive of the Vargas government of the 1930s, which adopted the model of substituting imports as an economic policy to overcome the crisis generated by the fallacy of the agricultural exports model that had been in place since colonial times (Baer, 2007; Bresser-Pereira, 1996).

It was only at this time that industry overtook agriculture in importance, and the metropolitan region of São Paulo emerged as the main industrial area of Brazil (Dean, 1969; Rattner, 1972), the true starting point for industrial management in Brazil. It is not by chance that São Paulo was chosen to be the city for the establishment of the first business schools in Brazil, especially the São Paulo School of Business Administration of the Getúlio Vargas Foundation (EAESP-FGV) and the Faculty of Economics, Administration and Accountancy of the University of São Paulo (FEA-USP), two of the most important learning and research institutions in the country for management (Bertero, 2006). 


\section{Some Implications of the Sustainability of the Rural Way of Life in the Brazilian Industrialization Process}

Different hues in the political, social and economic development of Brazil decisively influenced the pace and direction of the country's modernization. Despite beginning in the nineteenth century, Brazilian industrialization fell behind other countries undergoing the same process in other parts of the world. Therefore, we must consider that this turbulent period, marked especially by the persistence of colonial institutions and their influence on the development of modernization in Brazil, was decisive in forming the profile of Brazilian industry at the turn of the nineteenth century, when it began to be consolidated (Dean, 1969; Luz, 2004). In this sense, the delayed and turbulent epoch in which Brazilian industry was consolidated, has some interesting aspects to consider concerning the background of Brazilian management.

An important impact of the presence of a rural heritage was the sustainability of the slavery ideology and its lasting influence on the Brazilian political context (Leff, 1974). This fact was decisive in the tardiness of industrial development for almost a century after the first direct incentives (Graham, 1966; Leff, 1972; Skidmore, 1999; Stein, 1957). Furthermore, it is important to consider that the logic of slavery laid down such deep roots in Brazilian culture that it remained present in labor relations even after abolition in 1888, both in farming labor and in factories (Stein, 1957). It was the most significant cultural element in determining the conflicts of the early twentieth century between entrepreneurs and workers. These were mainly immigrants who were already familiar with the Trade Union system in Europe and would not passively accept the inhumane treatment that was the norm under slave labor (Dean, 1969; Skidmore, 1999).

Secondly, the different nationalist discourses that arose in the nineteenth century and early twentieth in order to justify or restrict or even combat the development of industry were intensely ideological in that they were not a legitimate defense of the nation but rather a defense of interest groups (Luz, 2004). In the first attempts to boost industrialization, the response of the government to the demands of the defenders of industry was to establish a form of protectionism that benefited some groups. It was of a clientelist nature that was typical of the relationship between the State and the upper classes (Luz, 2004). Considering that the traits of this stance of the elite remained in place during the twentieth century (Faoro, 2001), we may suppose that this continues still in the relationship between Brazilian companies and the State, something which has been pointed out by several writers (Bresser-Pereira, 1996; Castor, 2002). It is also important to note that the tutelage of industry by the State does not meet the interests of one group in total but rather the private interests of factions of this group, factions which, during the nineteenth century and beyond had more or less influence in the political sphere. This confirms the theory of Holanda (1995) that clientelism in the political discourse of the oligarchies indicates that the democracy common to the modern rule of law is only an ideological resource and does not represent the legitimate will of its proponents.

From the historical development of Brazilian institutions shown in this study, we may assume that certain aspects of the industrial management that was established in Brazil are possible reflections of pre-industrial heritage. Holanda (1995) mentions that in the 1930s it was common for many businessmen to undertake get rich quick ventures, an example of what the same author calls the adventurous spirit of the colonists. If we compare this with the theory of some writers on the irrational diversification (i.e., unplanned, inarticulate) that was characteristic of Brazilian industrial development in the early twentieth century, when a bazaar salesman mentality was developed, people "anxious to quickly pull out their investments, constantly seeking more profitable and speculative investments" (Rattner, 1972, p. 162), we can clearly see this colonial trait of the adventurer identified by Holanda (1995).

From the points set out in this study, we may highlight that another aspect concerning the implications of the sustainability of the rural way of life in the background of Brazilian management is the fact that Brazilian industrial management inherited a patrimonialist base of authority. One of 
the main aspects of this rural heritage is the personalistic logic of relationships of authority, i.e., that these relationships are characterized by the predominance of the personal power of the landowner. It can be seen as absolute power that is shown in work relations (especially between the master and the slave, but also between free rural workers), but also in other aspects of social life, such as marriage, family and even in the political sphere.

Modern management, marked by the characteristic impersonality of capitalist relationships of production that were established especially in the later stages of industrialization (Bendix, 1974; Braverman, 1998), arose in Brazil with the blemish of personalism left over from the country's colonial past. It is in this way that we identify patrimonialist authoritarianism in Brazilian companies (Barros \& Prates, 1996; Davel \& Vasconcelos, 1999); but we also find it in politics, especially in the predominance of personal interests over the public interest in the government.

Another trait of the patrimonialist heritage in relationships of authority in Brazilian companies is the paternalist way that things are done, especially the tendency to prioritize affection in relationships between managers and workers. This affectionate trait in relationships is due to the strong family unit in the sociological organization of the Brazilian rural model and which has penetrated into relationships of authority in Brazilian organizations as a tendency towards paternalism in relationships (Barros \& Prates, 1996). Thus, paternalism in the management of Brazilian organizations is characterized by the metaphor of a subservient child in the presence of his hero father; but at the same time this father is also a tyrant (Davel \& Vasconcelos, 1999).

One important aspect in the background of modern Brazilian management is seen in the declaration of Stein (1957) concerning the first textile factories in Brazil. The author claims that in the textile industries of the late nineteenth century, there was a fear of popular uprisings in Brazil like those which had occurred in Europe. This was why a good Samaritan policy was implemented, in which mechanisms for discipline and awards were established, in addition to awards for obedient workers. There were even exploitative acts that were justified as forming a good character. The author also points out that subservience and obedience were considered more important than skills or the capacity to produce in the earliest Brazilian factories.

\section{Two marks of Brazil's managerial path}

From the viewpoint of the organizational context, anachronistic Brazilian patrimonialism has led companies to partially adopt the modern management doctrines. Thus, the adoption of scientific management is marked by convenience rather than confrontation with the patrimonial base of authority. From this singular managerial guideline that has been established in industrialized Brazil, we highlight two points that mark the hybridism between rural heritage and the typical rationalization of the work of modern organizations: (a) opting for protectionism based on political influence and privileges extended to the businessman, which characterize relationships among the economic elite in Brazil; and (b) the subordination of formal authority and technical competence of the professional manager to patriarchal personalist logic, which favors family ties and personal loyalty. Let us now look at each of these points.

\section{First mark of the Brazilian managerial path: opportunistic protectionism over competitive competences}

The first factor that characterizes the Brazilian managerial path is the drive for competitive advantage by way of privileges gained through political ties. To a certain extent, the persistence of personalistic political bargaining in industrial enterprises compensated for the lack of rationalization in production (whether in terms of adopting new production technologies or the rationalization of management). Thus, even under pressure from external patterns of competition (given that imported products were available on the Brazilian market), the characteristic way of facing this threat was protectionism, looking after the interests of individuals or small groups, constructed through relations with the State. In other words, whenever a certain industry felt threatened by competition from a more 
efficient competitor, its directors would activate their network of political influence to minimize the threat. To a certain extent, this behavior became institutionalized as soon as the first genuine group of industrial businessmen was formed and even within trade associations (Leopoldi, 2000).

The extreme protectionism that configured the development of Brazilian industry following World War II was shown by the policy of substituting imports. This, coupled with the mentality of privileges that prevailed in the Brazilian imagination, was an important factor that led to the technological backwardness of many Brazilian companies. These companies rested on their laurels and took little notice of the development of other industrialized economies because the internal market had been guaranteed by the government.

In the policy of substituting imports, a measure that made a considerable impact was the severe enforcement of the so-called Similares law (law of similar products). Although this law was decreed in the late nineteenth century, this legislation was not actually put into practice until after World War II. The similar products law made it possible for Brazilian industries to request that their products be classified as a category in which imports were forced to pay a high currency exchange rate, thereby protecting themselves from competition from overseas competitors that made similar products. According to Baer (1997), the strict exchange policy of the 1950s, coupled with this classification of similar goods, encouraged intense vertical diversification in productive chains. This in turn led to a significant increase in the domestic production of essential inputs for industrial development.

Likewise, the enforcement of this law resulted in a growth in the number of multinational companies in the country. The MNCs were obliged to participate more directly in local industry in order not to risk losing out on the significant Brazilian market. As a study on American investment in Brazil at that time shows:

The Similares law was a very powerful incentive that made foreign investors shift from imports to assembly or from assembly to complete manufacturing. The essential feature of this incentive was fear of being completely excluded from the market rather than the hope of receiving better treatment than the competition. In many cases, the very mention that a Brazilian company or a competitor intended to enter the same line of business, implying that imports of similar goods would be banned at a future date, was enough to impel American companies to preserve their position in the market by building local factories (Gordon \& Grommers as cited in Baer, 1997, p. 74).

It is interesting to note that protectionism for people with special privileges has marked the industrialist movement since its early days in the nineteenth century (Luz, 2004). The claim for protection for Brazilian industry is marked by political disputes that surround the establishment of a true industrial policy by the government. However, this is essentially configured by disputes for privileges that were commonplace in colonial Brazil. Although industries were ideologically a class associated with modern political thinking, they were not above participating in this typical strategy, with deals being made behind closed doors rather than in legitimate forms of negotiations that were of interest to all.

We are not claiming that protectionist policies were not part of industrial development at other times and in other places. We should remember that even the English Industrial Revolution was marked by protectionist acts that were derived from the bellicose international policy of the British court (Hobsbawm, 1999). We are merely pointing out that protectionism in Brazil is marked by a clientelist design of the relationship between producers and the State. Thus, whether it is to protect crops or to protect industry, the significant trait of these policies in Brazil was an exchange of favors between the State and the elite, which were configured as protectionist and acting in the public interest rather than a policy that ensures privileges for the elite. We should point out that the roots of this social mentality lie in Brazil's remote colonial past. As an important Brazilian historian once said, during the rise of the industrial economy in Brazil, although oligarchic rural power had been unsettled, "this does not mean that the oligarchies disappeared, nor did it mean that the pattern of socio-political relationships based on 'exchanging favors' ceased to exist" (Fausto, 1999, p. 327). 


\section{Second mark of the Brazilian managerial path: personalistic basis of relationships and power over bureaucratic basis of authority}

The second factor that reveals the Brazilian managerial pattern is how the bureaucratic authority established in Brazilian companies is conditioned to the power of ownership and property. This patriarchal pattern did not cease to exist even within the multidivisional organization and open capital system that arose in Brazil in the first half of the twentieth century (Martins, 1973). This prerogative is revealing if we take into account that, according to Chandler's (1977) historical theory of big business, management is institutionalized as a result of the separation of ownership and managerial authority. This is the mark of the modern bureaucratic system as a reference of modern management, which constitutes technically legitimate authority (Bendix, 1974). This marks a paradox in the divisionalized and public corporation. In other words, the running of this company is not freely undertaken by professional administrators who are guided by rational and instrumental managerial principles and techniques.

The scenario of industrial development presented by Martins (1973) and Suzigan (2000) demonstrates that, until 1930, the Brazilian industrial reality already included a significant number of big mechanized, divisionalized and vertically and horizontally integrated companies. In spite of this, the full establishment of bureaucratic and professional managerial logic at that time was compromised by the fact that Brazilian companies in those days had not totally assimilated the logic of the separation of ownership and managerial control. Thus, an important aspect of these first large industrial enterprises was the tendency to view the owner as controller, even though most of these companies had adopted the open capital system. According to Cardoso (1972), many companies were becoming corporations without abolishing the controlling stake of the founding family. To this end, the legal artifice of Brazilian legislation was used, which allowed the issue of preferential sharers, i.e., shares without voting rights. It was therefore perfectly permissible for founding families with few shares to retain control of the enterprise.

This could be seen in several enterprises such as the largest company in the first half of the twentieth century, Indústrias Reunidas Francisco Matarazzo (Martins, 1973). However, according to Cardoso (1972), the trend of owner as controller is not in itself a contradiction within the industrialist economy; however, this author points out that in the Brazilian context the personalism of family relationships on the boards of open capital companies is something typically peculiar because in a way it characterizes the struggle between historically antagonistic trends.

Therefore, considering the tendency to rationalize management that stems from the intensification of industrialization, the continuing strong presence of the owners among the decision makers of big businesses in the first half of the twentieth century reflects an inclination that is contrary to the configuration of shareholder participation that is a characteristic of large monopolistic capitalist industries (Braverman, 1998; Cardoso, 1972; Chandler, 1977). This is due to the fact that this rationalization is considered a fundamental aspect to assure the necessary managerial efficiency for the bureaucratic structures that are developed within this type of organization. According to Cardoso (1972, p. 103), in the case of Brazil, "the pattern of control of enterprises implies the interference of the owners who exceed the natural limits of interference by shareholders in developed countries".

Therefore, under the aegis of the power of the families who own the company and the turbulent dynamic of personalistic relationships that result from this type of power, many of the most powerful industrial enterprises in São Paulo State were forced to close because of this contradictory patriarchal trend, which became a chronic problem especially during succession, and the lack of professionalism among managers. Two studies on this matter in the nineteen sixties showed that in addition to not being in a majority on the board of directors, the professional directors of companies in São Paulo at that time had no more than a $10 \%$ stake, and for this reason took part in few important decisions (Bresser-Pereira, 1996; Cardoso, 1972). Cardoso (1972) confirms that these professional directors remained on the boards of these companies because they bowed to the will of the non-professional owners. This fact is a reflection of the tendency to see ownership as a source of power and form of 
legitimizing authority, characterizing in these companies a system of typically patriarchal trust. On this point, Cardoso (1972, p. 124) comments that:

In companies that are under the direct supervision of members of the owner families or groups of shareholders, the director who is not a shareholder is usually a 'man of trust'. There are many channels for acquiring trust and they are only indirectly related to professional competence. When the companies are run by foreign families or controlled by descendants of immigrants who are in constant touch with the homeland of their ancestors; one of the important conditions for access to the positions that require great responsibility is to be of the same national origin as the owners. It is common in companies that belong to Italian families, for instance, to fill places on the board of directors that must be given to people outside the group by hiring Italians. It is often the case that someone with a high school diploma or graduate degree, but with no qualifications for managing a company, becomes a 'specialist' and is higher up in the company hierarchy than workers who have specialist qualifications that were obtained in Brazil.

The direct effect of this preponderance of property rights over the technical authority of professional administrators in the management of Brazilian companies was the difficulty they faced when dealing with basic matters of efficiency. Certainly, many of the problems of efficiency and productivity could have been easily resolved through acts of managerial rationalization that were already known at that time. Studies such as those of Cardoso (1972) and Bresser-Pereira (1996) concerning big Brazilian companies in the 1960s demonstrate this. Furthermore, the study conducted by Motta (1969) shows that one of the major characteristics of companies at that time was what this author referred to as the "generalized inefficiency of Brazilian companies" (p. 76), which corresponded to the problem of inflated costs resulting from productivity that was compromised because of the turbulent crisis of that decade but also because of problems of mismanagement, such as the wasteful use of energy and other inputs.

Contemporary studies suggest that this pattern continues until today. For example, Castor (2002) emphasizes that, in Brazilian companies, professional managers are used to dealing with personalistic and centralized structures when it comes to decision making. It is also common in the Brazilian context for owners to be directors of a company, even when they do not have the professional know-how for this task. Although this is by no means an exclusive pattern of Brazilian companies (in other countries, family businesses are also commonplace) in the Brazilian case, we are sharply reminded that there is still a hangover of colonial commandism even today. Although this patrimonialist trait in management of Brazilian companies is something widely accepted by researchers (and even consultants) who work for them, in this essay we have sought to highlight the historical origins of this fact in the turbulent history of industry in Brazil and, reaching further back, the rural heritage of the Brazilian colonial period.

\section{Conclusions}

In closing this essay, we must consider that if the transition of authority from the traditional kind to the authority of industrial order was problematic in the countries central to the world modernization process (Bendix, 1974), in Brazil this transition was much more complex. In this sense, it is necessary to understand the modernization process for management in this country more cautiously. For example, it is highly likely that it was due to this diverse historical background that the imported management models and references did not catch on very well in Brazil, as they were adopted only superficially, where discourse is quite unlike practice (Caldas \& Wood, 1997).

In this historical analysis, we get the impression that Brazilian industry was engendered by comfort and convenience, by immediate opportunism and short-term profit which, as we have seen, is an embedded cultural trait that dates back to colonial times. Thus, in the initial Brazilian industrialization process, the decision to undertake industrial ventures was made on the assumption of 
quick and easy profit, which was possible because of the extremely favorable economic and political conditions both internally and externally in the early decades of the twentieth century (Baer, 2007; Dean, 1969). It was for this reason that importers of heavy and voluminous products were compelled to produce them at home, owing to the difficulty of transporting them in a country of continental dimensions on precarious roads (Dean, 1969). Likewise, importers of durable goods and/or goods for production began to industrialize replacement parts to meet the immediate needs of their markets (Leff, 1982). The Great Depression and the world wars of the time meant that alternatives had to be sought for imports and for this reason the government took a stance that was favorable to the industrial sector.

Along with the neglect of technological innovation and marked by the inertia and lack of commitment to productivity, other indications of this colonial economic heritage are raised in some historiographical studies on the first period of expressive industrial activity in Brazil. These studies identify the relationship between the administrative incompetence of small and medium size companies and this provincial mentality of generating business (Dean, 1969; Rattner, 1972). Besides these authors, others have also pointed out the sustainability of the values of Brazilian rural society in the configuration of industrial management. For instance, Lopes (1971) conducted a study in the 1960s of a factory in São Paulo State and two in Minas Gerais and found that the values of Brazilian rural society were still predominant among the industrialists and the workers, values which were even stronger on the part of the workers. More recent studies indicate that, especially in family based companies, the clientelist tendency and the patriarchal style of management are strong traits in contemporary Brazilian management (Barros \& Prates, 1996; Davel \& Vasconcelos, 1999).

However, marked by extreme favoring and protectionism, this development model for domestic industry was a determining factor in the technological tardiness of Brazilian industries, as they fell behind the development of other industrialized economies. This is because the Brazilian government had guaranteed the domestic market for them. In an analysis on the current status of Brazilian companies, Castor (2002) points out that Brazilian companies did not know how to deal with the opening of the Brazilian market when the government lowered many protectionist barriers in the 1990s. This led to a process of internationalization of the control of big groups that were originally Brazilian, such as the household electrical appliances industry and the pharmaceutical sector. The author believes that this problem lies in the incapability of big companies to make the transition from an amateur enterprise (characteristic of the context of small companies) to a more competitive approach, centered on professional management.

Concerning the patrimonialist guidelines for running Brazilian companies, current analyses of Brazilian managerial style (e.g., Barros \& Prates, 1996) have corroborated this hypothesis. To complement these studies, this paper enables us to see with greater clarity the historical conditions that allowed this mentality to remain in place. And this is relevant if we take into consideration that studies of this Brazilian style adopt a reductionist vision of the formation of our society by assuming that these traits in our way of managing companies are cultural. The problem with viewing the situation this way can be seen in these studies through the tendency to consider Brazilian culture as something static and universal when in fact it is to a certain extent a historical construct. When we view the historical construct as a central element when attempting to understand the Brazilian way of managing, we emphasize the dynamism of these practices and our understanding of them shifts from carefully viewing them as natural to viewing them as historically localized and unique.

Another limitation of the culturalist studies of the Brazilian management style that deserves to be mentioned is that they totally disconnect it from the assumptions of modern management. On the contrary, following our historical review we can see just the opposite: by pointing out that Brazilian industrial management suffers because of a patrimonialist past, we do not mean that Brazilian industrialization was exempt from the principles of modern management. We must recognize that, in several aspects, the big Brazilian industrialists were in tune with the new management order that emerged from the Industrial Revolution. We can see this through the direct effort of the fledgling industrial class to constitute or develop the creation of management institutes and business schools, as was the case with the creation of the Rational Work Organization Institute (IDORT) in the nineteen 
thirties (Vizeu, 2008) and the business schools in São Paulo (EASP and FEA) in the mid twentieth century (Bertero, 2006).

Despite this, it is important to note that research indicates that technical administrative knowhow was only developed in most Brazilian businesses in the second half of the twentieth century (Curado, 2001). This gap between the emergence and management of big modern companies is yet another indicator of the importance of studying the heritage of pre-industrial times in order to understand management in Brazil, especially when examining the early stages of industrialization in this country.

Finally, our historical analysis reveals that the Brazilian pattern for social and economic development (and, consequently, managerial development) is one in which the modern and the conservative peacefully live side by side. Thus, historically, our organizations are receptive to modernization and improving managerial patterns and references as long as these new references can be mixed with the traditional patterns and values that continue to exist in our society. In other words, we adopt a modern behavior (and we are receptive to this pattern) but condition it through references to our patrimonialist past, especially when regulating relationships between private organizations and the State.

In the United States and the major industrialized European countries, the dissemination of modern management doctrines in companies was only undertaken because entrepreneurs were forced to hand over power to professional managers owing to the pressures of capitalist development (Braverman, 1998; Chandler, 1977). Therefore, the persistence of traits of a patrimonialist ethos in big Brazilian corporations was an obstacle that could compromise the full establishment of management in the country (Cardoso, 1972). This question opens new pathways for future studies that consider history as a fundamental factor when it comes to understanding the real conditions for the development of modern management in Brazil.

\section{Received 21 July 2009; received in revised form 10 August 2010.}

\section{Notes}

\footnotetext{
1 'Mandonismo' is an expression that derives from the word 'mando', which in Portuguese has a meaning similar to 'command'.

${ }^{2}$ This term refers to the practice of becoming a compadre, a Portuguese expression for the closeness of being a baptismal godparent. In this sense, Canabrava (1985) and Holanda (1995) say that it was common for less well-off members of the community to ask the mill owner to be a godparent at their child's baptism, thereby showing that this practice was common at different social levels. This emphasizes the idea that social relations were of a markedly personal nature.
}

\section{References}

Baer, W. (2007). The Brazilian economy: its growth and development. (6th ed.). Westport, CT: Praeger Publishers.

Barros, B. T., \& Prates, M. A. S. (1996). O estilo brasileiro de administrar. São Paulo: Atlas.

Bendix, R. (1974). Work and authority in industry: ideologies of management in course of industrialization. Berkeley: University California Press.

Bertero, C. O. (2006). Ensino e pesquisa em administração. São Paulo: Thomson Learning.

Braverman, H. (1998). Labor and monopoly capitalism (25th ed.). New York: Monthly Review Press. 
Bresser-Pereira, L. C. (1996). Economic crisis and state reform in Brazil. Boulder, CO: Lynne Rienner.

Caldas, M., \& Wood, T., Jr. (1997). For the English to see: the importation of managerial technology in late $20^{\text {th }}$ Century Brazil. Organization, 4(4), 517-534. doi: 10.1177/135050849700400410

Canabrava, A. P. A. (1985). A grande propriedade rural. In S. B. Holanda (Ed.), História geral da civilização Brasileira: a época colonial (pp. 192-217). São Paulo: Difel.

Cardoso, F. H. (1972). Empresário industrial e desenvolvimento econômico no Brasil (2nd ed.). São Paulo: Difusão Européia do Livro.

Carvalho, J. M. (1998). Pontos e bordados: escritos de História política. Belo Horizonte: Editora da UFMG.

Castor, B. V. J. (2002). Brazil is not for amateurs: patterns of governance in the land of "jeitinho". USA: Xlibris.

Chandler, A. D. (1977). The visible hand: the managerial revolution in American business. Cambridge: Harvard University Press.

Curado, I. B. (2001). O desenvolvimento dos saberes administrativos em São Paulo: uma abordagem histórica. Doctoral dissertation, Fundação Getúlio Vargas, São Paulo, SP, Brazil.

DaMatta, R. (1992). Carnivals, rogues and heroes. Indiana: Notre Dame Press.

Davel, E., \& Vasconcelos, J. (1999). Gerência e autoridade nas empresas brasileiras: uma reflexão histórica e empírica sobre a dimensão paterna nas relações de trabalho. In M. P. Caldas \& F. C. P. Motta (Eds.), Cultura organizacional e cultura brasileira (pp. 94-110). São Paulo: Atlas.

Dean, W. (1969). The industrialization of São Paulo: 1880-1945. Austin: University of Texas Press.

Faoro, R. (2001). Os donos do poder (3rd ed.). São Paulo: Globo.

Fausto, B. (1999). A concise history of Brazil. Cambridge: Cambridge University Press.

Freyre, G. (2003). Casa grande e senzala (47th ed.). São Paulo: Global.

Furtado, C. (1999). A formação econômica do Brasil (27th ed.). São Paulo: Companhia Editorial Nacional.

Graham, R. (1966). Causes for the abolition of Negro slavery in Brazil: an interpretive essay. The Hispanic American Historical Review, 46(2), 123-137.

Graham, R. (1968). Britain and the onset of modernization in Brazil. Cambridge: Cambridge University Press.

Graham, R. (1981). Slavery and economic development: Brazil and the United States south in the nineteenth century. Comparative Studies in Society and History, 23(4), 620-655. doi: 10.1017/S001041750001358X

Hobsbawm, E. J. (1988). The age of capital. Michigan: Abacus.

Hobsbawm, E. J. (1999). Industry and empire: the birth of Industrial Revolution. Canada: The New Press.

Holanda, S. B. (1995). Raízes do Brasil (26th ed.). São Paulo: Companhia das Letras. 
Jacques, R. S. (1996). Manufacturing the employee: management knowledge from the $19^{\text {th }}$ to $21^{\text {st }}$ centuries. London: Sage.

Leff, N. H. (1972). Economic retardation in nineteenth-century Brazil. Economic History Review, 25(3), 489-507. doi: 10.1111/j.1468-0289.1972.tb02189.x

Leff, N. H. (1974). Long-term viability of slavery in a backward closed economy. Journal of Interdisciplinary History, 5(1), 103-108.

Leff, N. H. (1982). Underdevelopment and development in Brazil. London: Allen \& Unwin.

Leopoldi, M. A. P. (2000). Política e interesses na industrialização brasileira. São Paulo: Paz e Terra.

Lopes, J. R. B. (1971). Sociedade industrial no Brasil (2nd ed.). São Paulo: Difusão Européia do Livro.

Luz, N. V. (2004). A luta pela industrialização no Brasil (3rd ed.). São Paulo: Alfa-Omega.

Martins, J. S. de (1973). Conde Matarazzo, o empresário e a empresa. São Paulo: Hucitec.

Motta, F. C. P. (1969). O racionalismo capitalista e a evolução da empresa brasileira. Master's degree thesis, Fundação Getúlio Vargas, São Paulo, SP, Brazil.

Needell, J. (2001). Provincial origins of the Brazilian state: Rio de Janeiro, the monarchy, and national political organization, 1808-1853. Latin American Research Review, 36(3), 132-153.

Pollard, S. (1965). The genesis of modern management: a study of the Industrial Revolution in Great Britain. Cambridge: Harvard University Press.

Prado, C., Jr. (1971). Formação do Brasil contemporâneo (11th ed.). São Paulo: Brasiliense.

Rattner, H. (1972). Industrialização e concentração econômica em São Paulo. Rio de Janeiro: FGV.

Ridings, E. W. (1977). Interest groups and development: the case of Brazil in the Nineteenth Century. Journal of Latin American Studies, 9(2), 225-250. doi: 10.1017/S0022216X00020599

Skidmore, T. E. (1999). Brazil: five centuries of change. Oxford: Oxford University Press.

Stein, S. J. (1957). The Brazilian cotton manufacture. Cambridge: Harvard University Press.

Suzigan, W. (2000). Indústria brasileira: origem e desenvolvimento. Campinas: Hucitec.

Vizeu, F. (2008). Management no Brasil em perspectiva histórica: o projeto do IDORT nas décadas de 1930 e 1940. Doctoral dissertation, Fundação Getúlio Vargas, São Paulo, SP, Brazil. 